\title{
Managerial competencies - A survey of hospital managers' working in Kathmandu valley, Nepal
}

\author{
Deepak Kumar Khadka ${ }^{1}$, Milan Gurung ${ }^{2}$, Nawaraj Chaulagain ${ }^{3}$ \\ 1. Department of Health Care Management, National Open College, Faculty of Management Studies, Pokhara University, \\ Nepal. 2. Hospital Administration, Scheer Memorial Hospital of Seventh Day Adventist, Banepa, Kavre, Nepal. 3. Human \\ Resources Department, Tilganga Institute of Ophthalmology, Gaushala, Kathmandu, Nepal.
}

Correspondence: Deepak Kumar Khadka. Address: Department of Health Care Management, National Open College, Faculty of Management Studies, Pokhara University, Nepal. E-mail: deepak.khadka@mail-me.com

Received: July 4, 2013

DOI : 10.5430/jha.v3n1p62

Online Published: October 11, 2013

Accepted: September 22, $2013 \quad$ Onlin
URL: http://dx.doi.org/10.5430/jha.v3n1p62

\section{Abstract}

Background: Managerial competencies are sets of knowledge, skills, behaviors and attitudes that a person needs to be effective in a diverse managerial job. This study sets out at assessing the level and gap of current actual and ideal required competency, important competency statement, and association between respondents' biographics with a current actual competency level of hospital manager.

Methods: A cross-sectional survey used self-administered questionnaire based on Senior Management Service (SMS) competency framework of Department of Public Service and Administration (DPSA) for health manager consists of a set of eleven generic competencies conducted purposively in fifty-one hospital managers working within the Kathmandu Valley. Individual variables were summarized using frequency distribution focused on central tendency and dispersion. Relationships between variables analyzed by using one-way analysis of variance (ANOVA) and significance of difference in the competency profile determined by Wilcoxon signed rank test.

Results: Highest self-assessed most developed competencies were honesty and integrity, service delivery innovation, and communication and information. The least developed were program and project management and knowledge management. Most important competencies regarded as strategic capability and leadership; and human resources management and empowerment. Significant gap exists in all generic competencies except communication and information and, honesty and integrity. There was no any significant association between respondents' biographics with current actual competency level.

Conclusions: Findings back up the belief of managerial competency lacking and enormous need for development which reflects the local hospital management environment reality. Innovative approaches of management development programs and formal academic programs can improve and link the competency gap among hospital managers of Nepal.

\section{Key words}

Hospital management, Hospital manager, Managerial competencies, Current actual competency, Ideal required competency, Competency gaps, Nepal

\section{I ntroduction}

Hospitals are important vehicles for the delivery of health care, and managers of these institutions are to a large extent 
responsible for operationalizing the visions and objectives that policy-makers have for the health and well-being of a nation ${ }^{[1]}$. Managing healthcare institution depends upon the key competencies of managers responsible for the operation of hospital amenities.

Management is a fine blend of many different subjects and disciplines that can be hard to define and even harder to learn. Management is not confined to the fore walls of the industry; it is indispensable everywhere whether it be a hospital, an educational institution, agriculture, army, trade-union, government administration, charitable institution, club or one's own home. Management is that "What managers do" ${ }^{[2]}$.

Managers need to possess several competencies that will enable them to perform managerial functions effectively and efficiently. Managerial competencies are sets of knowledge, skills, behaviors, and attitudes that a person needs to be effective in a wide range of managerial jobs and various types of organizations ${ }^{[3]}$.

Despite recent increases in development assistance for health, most low-income countries are not progressing well towards achieving the health-related Millennium Development Goals ${ }^{[4]}$. Weaknesses in general managerial capacity at all levels of health systems have been cited as one of the contributory factors to this failure in scaling up health services and achieving health goals ${ }^{[5]}$.

Hospital-specific management practices are strongly related to a hospital's quality of patient care and productivity outcomes. Improved management practices in hospitals are associated with significantly lower mortality rates and better financial performance. There is significant variation in the quality of hospital management practices suggests a great opportunity for improvement in poorly performing hospitals. There is a strong relationship between a number of factors and effective management practices ${ }^{[6]}$.

Lack of competencies and skills of managers in hospital consequently related to inefficient allocation of resources, quality and outcome of health care services. Roles, competencies and skills of hospital manager directly have an impact on the efficient management of the hospital and that also helps to sustain services. A numerous studies have been carried out in regards to the competencies of hospital managers; Nepalese studies are limited in that most and given a noticeable lack, this study will attempt to address the gap in literature associated with healthcare management. Existing information on the availability of tertiary, referral care and super-specialty hospitals indicates that they are more concentrated in the urban areas of Nepal mostly in the metropolitan cities like Kathmandu Valley which comprised of the three major districts; Kathmandu, Bhaktapur and Lalitpur ${ }^{[7]}$.

The main objectives of the study were to assess the managerial competencies of hospital manager working within the vicinity of Kathmandu Valley aims at assessing the level of current actual and ideal required competency, gaps in competency profile, important competency statement as regarded by respondent, and the association between biographical characteristics and current actual competency level of hospital manager.

\section{Methods}

Data for this study came from a cross-sectional survey using a self-administered questionnaire was conducted among all hospital managers of Kathmandu Valley. A pre-tested structured self-administered questionnaire was used during the period of June to July 2012 to collect the preliminary data from the respective respondent. The psychometric responses questionnaire with non-comparable four-point scales comprised of 93 competency statements were used to raise the managerial competency level of hospital manager with a set of eleven generic competencies which competent hospital manager can independently develop and applies more advanced concepts and methods, plans and guides the work of others and performs the analysis.

This study is based on the proficiency level of Competent (see Table 1). The competencies that appear in the Senior Management Service (SMS) Competency Framework are in no order of importance to the role of managers. All the eleven 
generic competencies are viewed as being critical for high performance in the manager's role ${ }^{[8]}$ :

- Strategic Capability and Leadership - The manager should be able to provide a vision, set the direction for the organization and inspire others in order to deliver on the organizational mandate.

- Program and Project Management - The manager should be able to plan, manage, monitor and evaluate specific activities in order to deliver the desired outputs.

- Financial Management - The manager should be able to compile and manage budgets, control cash flow, institute risk management and administer tender procurement processes in accordance with generally recognized financial practices in order to ensure the achievement of strategic organizational objectives.

- Change Management - The manager should be able to initiate and support organizational transformation and change in order to successfully implement new initiatives and deliver on service delivery commitments.

- Knowledge Management - The manager should be able to promote the generation and sharing of knowledge and learning in order to enhance the collective knowledge of the organization.

- Service Delivery Innovation - The manager should be able to explore and implement new ways of delivering services that contribute to the improvement of organizational processes in order to achieve organizational goals.

- Problem Solving and Analysis - The manager should be able to systematically identify, analyze and resolve existing and anticipated problems in order to reach optimum solutions in a timely manner.

- Human Resources Management and Empowerment - The manager should be able to manage and encourage people, optimize their outputs and effectively manage relationships in order to achieve organizational goals.

- Client Orientation and Customer Focus - The manager should be willing and able to deliver services effectively and efficiently in order to put the spirit of customer service into practice.

- Communication and Information - The manager should be able to exchange information and ideas in a clear and concise manner appropriate for the audience in order to explain, persuade, convince and influence others to achieve the desired outcomes.

- Honesty and Integrity - The manager should be able to display and build the highest standards of ethical and moral conduct in order to promote confidence and trust in the customers' service.

Table 1. Components of the SMS competency framework

\begin{tabular}{|c|c|c|c|c|c|}
\hline \multirow{2}{*}{$\begin{array}{l}\text { Competency } \\
\text { Name }\end{array}$} & \multirow{2}{*}{$\begin{array}{l}\text { Competency } \\
\text { Definition }\end{array}$} & \multicolumn{4}{|c|}{ Proficiency Level } \\
\hline & & Basic & Competent & Advanced & Expert \\
\hline $\begin{array}{l}\text { Name used to } \\
\text { identify the } \\
\text { Manager's } \\
\text { behavior or } \\
\text { groupings of } \\
\text { behaviours. }\end{array}$ & $\begin{array}{l}\text { General description } \\
\text { of behaviors and } \\
\text { activities that must } \\
\text { be demonstrated by } \\
\text { Managers to } \\
\text { achieve the desired } \\
\text { competency. }\end{array}$ & $\begin{array}{l}\text { Applies basic } \\
\text { concepts and } \\
\text { methods but } \\
\text { required } \\
\text { supervision } \\
\text { and coaching. }\end{array}$ & $\begin{array}{l}\text { Independently } \\
\text { develops and applies } \\
\text { more advanced } \\
\text { concepts and methods. } \\
\text { Plans and guides the } \\
\text { work of others. } \\
\text { Performs analysis. }\end{array}$ & $\begin{array}{l}\text { Understands and applies } \\
\text { more complex concepts } \\
\text { and methods. Leads and } \\
\text { directs people or groups } \\
\text { recognized specialists. } \\
\text { Able to perform in-depth } \\
\text { analysis. }\end{array}$ & $\begin{array}{l}\text { Sought out for } \\
\text { deep, specialized } \\
\text { expertise. Leads } \\
\text { the direction of the } \\
\text { organization. } \\
\text { Defines a } \\
\text { model/theory. }\end{array}$ \\
\hline
\end{tabular}

These key managerial competencies were derived from the SMS competency framework of DPSA (Department of Public Service and Administration) for health manager and leaders in South Africa ${ }^{[8]}$. Those competencies are viewed as being critical for high performance in the manager's role and the framework focused on critical generic competencies, which managers would be expected to possess, rather to functional or, technical which are essential to a specific job. A set of eleven generic competencies communicates what is expected of managers seeks to establish a shared understanding of critical success factors for performance in management and this does not describe the functions or responsibilities of 
particular management levels. Content validity of this questionnaire was assessed with the expert panel review of the Research Ethics Committee of National Open College, Pokhara University composed of five members including Research Professors, Research Coordinators and Hospital Managers. One Focus Group Discussion (FGD) was conducted among seven Hospital Managers and questionnaire was pre-tested in three hospitals of Kathmandu Valley to assess psychometric responses and content validity. After the decision of expert panel review, and results from FGD and pre-testing, revisions were made on the proficiency level with an exclusion of -Basic, Advanced and Expert- and inclusion of -Competent proficiency level for this study. Reliability of the instrument was tested by using Cronbach's alpha coefficient, which assess the internal consistency of the entire scale. The internal consistency of the scale for this data was excellent $(\alpha \geq 0.9)$. This SMS Competency Framework is used by DPSA for recruitment, performance management and training of managers of the Public Service Administration of Republic of South Africa. So the framework developed by the DPSA subsequently reconstructed the content validity and reliability of the instrument.

Likert-type 1-4 scales were regarded as; 4 as very competent (capable of performing and practicing regularly), 3 as competent (capable of performing but don't practice regularly), 2 as competency needs improvement (little experience performing), and 1 as no competency (no experience) for current actual competency profile and competency scales regarded as; 1 as unimportant, 2 as less important, 3 as important and, 4 as extremely important for ideal required competency profile.

Questionnaires were distributed via email and by meeting directly to the targeted respondent. The entire hospital of the Kathmandu Valley was taken as a study population with inclusion criteria of professionals currently designated as a Hospital Director, Hospital Manager, Hospital Administrator and, or Hospital Administrative Officer responsible for the day to day administration and operation of hospital amenities with a minimum of baccalaureate degree (or equivalent) obtained in any academic discipline was included for this study.

While collecting the data, verbal consent was taken from the participants. Subsequently, researcher clarifies study objectives with ensuring confidentiality and voluntary withdrawal from the study. Ethical approval was obtained from the Research Ethics Committee of the National Open College affiliated to Pokhara University, Nepal. Data were entered into Microsoft Excel and analyzed in the Statistical Packages for Social Science (SPSS) 16.0 version. Data for individual variables were summarized using frequency distribution and focused on the central tendency (mean, median, and mode) and the dispersion (standard deviation) with findings was presented in the median for the reason that skewed data sets. Reliability of the instrument was tested by using Cronbach's alpha coefficient which assessed the internal consistency of the entire scale. Difference in competency profile was tested by using Wilcoxon signed ranks test and association between respondents' biographics and current actual competency level was tested by using one-way analysis of variance (ANOVA); Kruskal-Wallis and Mann-Whitney $U$ test with $p>.05$. All analysis was conducted on $95 \%$ confidence interval (CI) with allowing a 5\% margin error.

\section{Results}

Of the 77 questionnaires distributed, 51 were returned from the respondents representing a response rate of $66.23 \%$. The internal consistency of the scale for this data was excellent $(\alpha \geq 0.9)$ for both current actual competency $(\alpha=0.9485)$ and ideal required competency $(\alpha=0.9668)$ as reliability tests were done by using Cronbach's alpha coefficient.

The age of respondents was from 21 years to 60 years with the majority $(45.1 \%, \mathrm{n}=23)$ represents the age group of 31 years-40 years. Out of total respondent $84.3 \%(\mathrm{n}=43)$ of the respondents were male and from private hospitals $(64.7 \%$, $\mathrm{n}=33)$. Almost $45 \%(\mathrm{n}=23)$ respondents were currently working as a hospital manager/administrator represents middle level managers $(37.3 \%, \mathrm{n}=19)$ responsible for tactical jobs according to management hierarchy and level of management. The majority of the managers $(66.7 \%, \mathrm{n}=34)$ had obtained masters or higher academic degree and from the non- 
administrative academic discipline $(41.2 \%, \mathrm{n}=21)$ currently managing the hospital. Similarly, $39.2 \%(\mathrm{n}=20)$ of the respondent obtained concentration degree in healthcare or, hospital management. Around 59\% $(\mathrm{n}=30)$ respondent have had no any formal training attained in regards to hospital management and administration. The majority of the respondent $(41.2 \%, \mathrm{n}=21)$ had experienced in managing hospital for three years to eight years and $21.6 \%(\mathrm{n}=11)$ have less than three years of tenure in hospital management (see Table 2).

Table 2. Biographical information of respondents

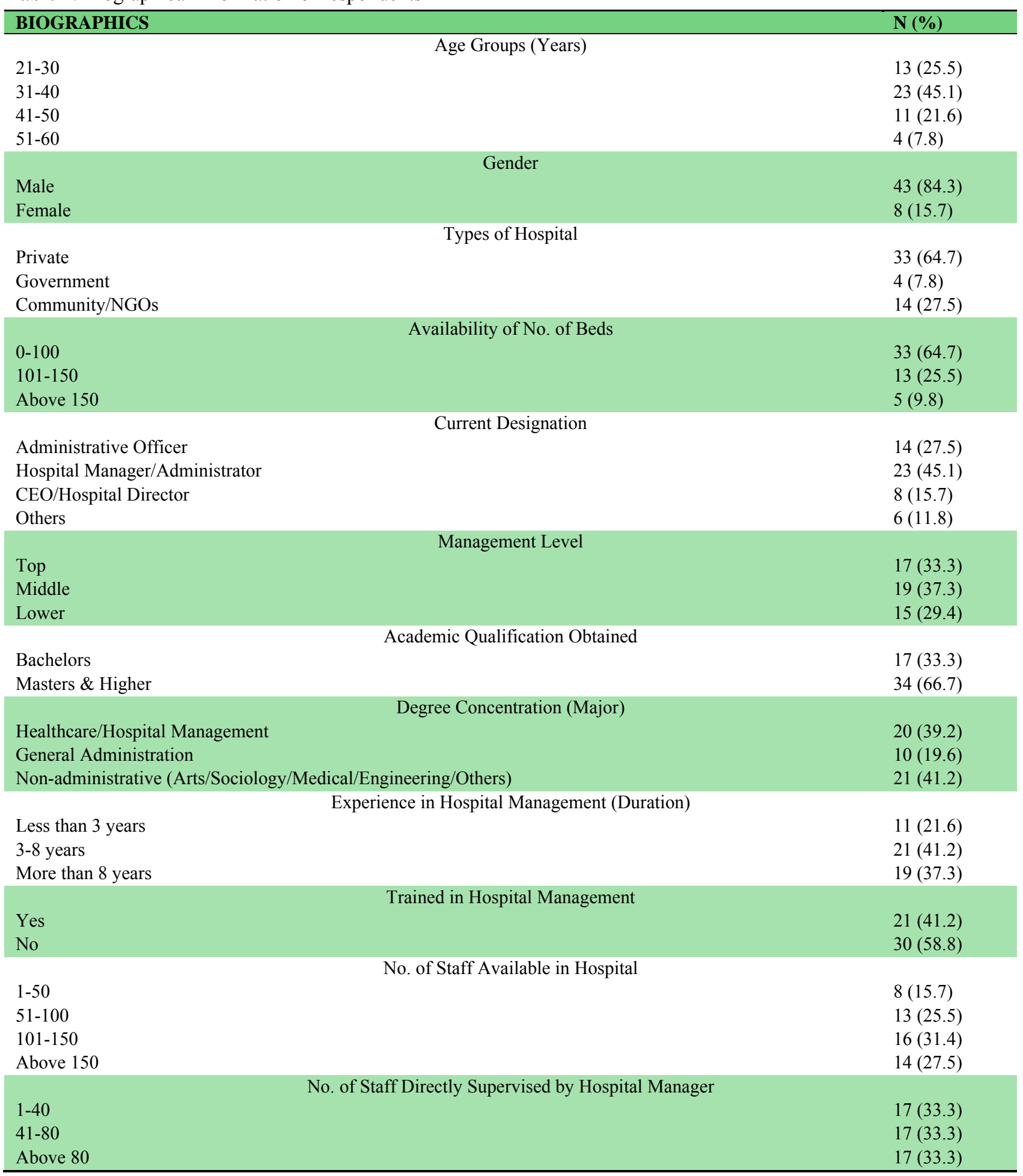


The self assessed most developed current actual competencies were honesty and integrity, service delivery innovation and communication and information. Least developed current actual competencies were program and project management and knowledge management for the reason that they are currently not employing this competency very well in managerial practices in a hospital setting. Respondents rated the highest for honesty and integrity, client orientation and customer focus, problem solving and analysis, these competencies were regarded as integral to the hospital manager for future tenure. Similarly they felt change management and, program and project management are least important competency components for hospital managerial practice for future (see Table 3).

Table 3. Competency profiles of respondent

\begin{tabular}{|c|c|c|c|c|c|c|c|c|}
\hline \multirow{2}{*}{$\begin{array}{l}\text { Competency Profiles of } \\
\text { Respondents }(\mathrm{N}=51)\end{array}$} & \multirow{2}{*}{ Level } & \multirow{2}{*}{ Mean } & \multirow{2}{*}{ Median } & \multirow{2}{*}{ SD } & \multirow{2}{*}{ Min } & \multirow{2}{*}{ Max } & \multicolumn{2}{|c|}{ Quartiles } \\
\hline & & & & & & & Q1 & Q3 \\
\hline Strategic Capability \& & $\mathrm{CA}$ & 3.22 & 3.30 & 0.44 & 2.40 & 4.00 & 2.80 & 3.50 \\
\hline Leadership & IR & 3.43 & 3.50 & 0.46 & 2.30 & 4.00 & 3.10 & 3.80 \\
\hline Program \& Project & $\mathrm{CA}$ & 3.12 & 3.13 & 0.50 & 1.25 & 4.00 & 2.88 & 3.38 \\
\hline Management & IR & 3.38 & 3.38 & 0.47 & 2.13 & 4.00 & 3.00 & 3.75 \\
\hline \multirow{2}{*}{ Financial Management } & $\mathrm{CA}$ & 3.16 & 3.23 & 0.62 & 1.38 & 4.00 & 2.77 & 3.62 \\
\hline & IR & 3.39 & 3.46 & 0.57 & 1.62 & 4.00 & 3.00 & 3.92 \\
\hline \multirow{2}{*}{ Change Management } & $\mathrm{CA}$ & 3.09 & 3.25 & 0.54 & 1.75 & 4.00 & 2.75 & 3.50 \\
\hline & IR & 3.28 & 3.38 & 0.59 & 1.63 & 4.00 & 2.88 & 3.88 \\
\hline \multirow{2}{*}{ Knowledge Management } & $\mathrm{CA}$ & 3.09 & 3.13 & 0.49 & 1.88 & 4.00 & 2.75 & 3.50 \\
\hline & IR & 3.45 & 3.50 & 0.48 & 1.88 & 4.00 & 3.13 & 3.88 \\
\hline Service Delivery & $\mathrm{CA}$ & 3.29 & 3.50 & 0.55 & 1.83 & 4.00 & 3.00 & 3.67 \\
\hline Innovation & IR & 3.47 & 3.50 & 0.55 & 1.67 & 4.00 & 3.17 & 4.00 \\
\hline \multirow{2}{*}{$\begin{array}{l}\text { Problem Solving \& } \\
\text { Analysis }\end{array}$} & $\mathrm{CA}$ & 3.19 & 3.20 & 0.48 & 2.00 & 4.00 & 3.00 & 3.60 \\
\hline & IR & 3.42 & 3.60 & 0.56 & 1.80 & 4.00 & 3.20 & 4.00 \\
\hline \multirow{2}{*}{$\begin{array}{l}\text { HR Management \& } \\
\text { Empowerment }\end{array}$} & $\mathrm{CA}$ & 3.24 & 3.36 & 0.53 & 1.45 & 4.00 & 3.00 & 3.55 \\
\hline & IR & 3.40 & 3.45 & 0.57 & 1.73 & 4.00 & 3.00 & 4.00 \\
\hline \multirow{2}{*}{$\begin{array}{l}\text { Client Orientation \& } \\
\text { Customer Focus }\end{array}$} & $\mathrm{CA}$ & 3.22 & 3.20 & 0.61 & 1.40 & 4.00 & 2.80 & 3.80 \\
\hline & IR & 3.52 & 3.60 & 0.59 & 1.80 & 4.00 & 3.20 & 4.00 \\
\hline \multirow{2}{*}{$\begin{array}{l}\text { Communication \& } \\
\text { Information }\end{array}$} & $\mathrm{CA}$ & 3.26 & 3.38 & 0.57 & 1.88 & 4.00 & 2.88 & 3.75 \\
\hline & IR & 3.42 & 3.50 & 0.61 & 1.88 & 4.00 & 3.00 & 3.88 \\
\hline \multirow{2}{*}{ Honesty \& Integrity } & $\mathrm{CA}$ & 3.55 & 3.73 & 0.50 & 1.82 & 4.00 & 3.36 & 3.91 \\
\hline & IR & 3.56 & 3.73 & 0.58 & 1.55 & 4.00 & 3.36 & 4.00 \\
\hline Overall Competency & $\mathrm{CA}$ & 3.22 & 3.35 & 0.43 & 1.92 & 4.00 & 2.90 & 3.50 \\
\hline Score & IR & 3.42 & 3.46 & 0.48 & 1.90 & 4.00 & 3.23 & 3.89 \\
\hline
\end{tabular}

Note. $\mathrm{CA}=$ Current Actual, $\mathrm{IR}=$ Ideal Required, $\mathrm{HR}=$ Human Resources

In order to establish the developmental needs of hospital manager, the current actual competency was compared to ideal required level of competency. The significant difference exists in all generic competencies except communication and information $(p=.075)$ and, honesty and integrity $(p=.459)$ with $\mathrm{p}$ value is greater than $(p>.05)$ at $95 \%$ CI tested by using Wilcoxon signed ranks test based on the median difference (see Table 4).

According to the priority ratings of respondents among eleven generic competencies, strategic capability and leadership was regarded as first and human resources management and empowerment as second important competency for hospital managers. In that order the least prioritized competencies were change management, financial management and program and project management in their current managerial practice in a hospital setting as these competencies are not practicing regularly by hospital managers. Priority ratings were determined by using mode score (see Table 5). 
Table 4. Competency difference (gap) of respondents

\begin{tabular}{|c|c|c|c|c|c|c|c|c|c|c|}
\hline \multirow{2}{*}{$\begin{array}{l}\text { Competency } \\
\text { Variables }(N=51)\end{array}$} & \multirow{2}{*}{ Level } & \multirow{2}{*}{ Mean } & \multirow{2}{*}{ Median } & \multirow{2}{*}{ SD } & \multirow{2}{*}{ Min } & \multirow{2}{*}{ Max } & \multicolumn{2}{|c|}{ Quartiles } & \multirow{2}{*}{$\mathbf{Z}$} & \multirow{2}{*}{$\begin{array}{l}P \text {-Value } \\
\text { (Sig.2-tailed) }\end{array}$} \\
\hline & & & & & & & Q1 & Q3 & & \\
\hline \multirow{2}{*}{$\begin{array}{l}\text { Strategic Capability } \\
\& \text { Leadership }\end{array}$} & CA & 3.22 & 3.30 & 0.44 & 2.40 & 4.00 & 2.80 & 3.50 & \multirow{2}{*}{-3.121} & \multirow{2}{*}{.002} \\
\hline & IR & 3.43 & 3.50 & 0.46 & 2.30 & 4.00 & 3.10 & 3.80 & & \\
\hline \multirow{2}{*}{$\begin{array}{l}\text { Program \& Project } \\
\text { Management }\end{array}$} & CA & 3.12 & 3.13 & 0.50 & 1.25 & 4.00 & 2.88 & 3.38 & \multirow{2}{*}{-3.442} & \multirow{2}{*}{.001} \\
\hline & IR & 3.38 & 3.38 & 0.47 & 2.13 & 4.00 & 3.00 & 3.75 & & \\
\hline \multirow{2}{*}{$\begin{array}{l}\text { Financial } \\
\text { Management }\end{array}$} & $\mathrm{CA}$ & 3.16 & 3.23 & 0.62 & 1.38 & 4.00 & 2.77 & 3.62 & \multirow{2}{*}{-2.782} & \multirow{2}{*}{.005} \\
\hline & IR & 3.39 & 3.46 & 0.57 & 1.62 & 4.00 & 3.00 & 3.92 & & \\
\hline \multirow{2}{*}{$\begin{array}{l}\text { Change } \\
\text { Management }\end{array}$} & $\mathrm{CA}$ & 3.09 & 3.25 & 0.54 & 1.75 & 4.00 & 2.75 & 3.50 & \multirow{2}{*}{-2.581} & \multirow{2}{*}{.010} \\
\hline & IR & 3.28 & 3.38 & 0.59 & 1.63 & 4.00 & 2.88 & 3.88 & & \\
\hline \multirow{2}{*}{$\begin{array}{l}\text { Knowledge } \\
\text { Management }\end{array}$} & CA & 3.09 & 3.13 & 0.49 & 1.88 & 4.00 & 2.75 & 3.50 & \multirow{2}{*}{-4.111} & \multirow{2}{*}{.000} \\
\hline & IR & 3.45 & 3.50 & 0.48 & 1.88 & 4.00 & 3.13 & 3.88 & & \\
\hline \multirow{2}{*}{$\begin{array}{l}\text { Service Delivery } \\
\text { Innovation }\end{array}$} & $\mathrm{CA}$ & 3.29 & 3.50 & 0.55 & 1.83 & 4.00 & 3.00 & 3.67 & \multirow{2}{*}{-2.016} & \multirow{2}{*}{.044} \\
\hline & IR & 3.47 & 3.50 & 0.55 & 1.67 & 4.00 & 3.17 & 4.00 & & \\
\hline \multirow{2}{*}{$\begin{array}{l}\text { Problem Solving \& } \\
\text { Analysis }\end{array}$} & CA & 3.19 & 3.20 & 0.48 & 2.00 & 4.00 & 3.00 & 3.60 & \multirow{2}{*}{-3.029} & \multirow{2}{*}{.002} \\
\hline & IR & 3.42 & 3.60 & 0.56 & 1.80 & 4.00 & 3.20 & 4.00 & & \\
\hline \multirow{2}{*}{$\begin{array}{l}\text { HR Management \& } \\
\text { Empowerment }\end{array}$} & CA & 3.24 & 3.36 & 0.53 & 1.45 & 4.00 & 3.00 & 3.55 & ברק 2 & 026 \\
\hline & IR & 3.40 & 3.45 & 0.57 & 1.73 & 4.00 & 3.00 & 4.00 & -2.222 & $.0 \angle 0$ \\
\hline Client Orientation & $\mathrm{CA}$ & 3.22 & 3.20 & 0.61 & 1.40 & 4.00 & 2.80 & 3.80 & 3122 & 007 \\
\hline$\&$ Customer Focus & IR & 3.52 & 3.60 & 0.59 & 1.80 & 4.00 & 3.20 & 4.00 & -3.122 & .002 \\
\hline Communication \& & $\mathrm{CA}$ & 3.26 & 3.38 & 0.57 & 1.88 & 4.00 & 2.88 & 3.75 & -1780 & 075 \\
\hline Information & IR & 3.42 & 3.50 & 0.61 & 1.88 & 4.00 & 3.00 & 3.88 & -1.100 & \\
\hline Unnocty \& Intority & $\mathrm{CA}$ & 3.55 & 3.73 & 0.50 & 1.82 & 4.00 & 3.36 & 3.91 & 0741 & 150 \\
\hline & IR & 3.56 & 3.73 & 0.58 & 1.55 & 4.00 & 3.36 & 4.00 & & \\
\hline
\end{tabular}

Note. $\mathrm{CA}=$ Current Actual, IR = Ideal Required, $\mathrm{HR}=$ Human Resources

Table 5. Important competency component (priority ratings)

\begin{tabular}{lll}
\hline Priority Ratings (1 to 11) & N (\%) & Mode Score \\
\hline Strategic Capability \& Leadership & $32(62.7)$ & 1 \\
Program \& Project Management & $11(21.6)$ & 8 \\
Financial Management & $12(23.5)$ & 9 \\
Change Management & $9(17.6)$ & 10 \\
Knowledge Management & $10(19.6)$ & 7 \\
Service Delivery Innovation & $9(17.6)$ & 7 \\
Problem Solving \& Analysis & $7(13.7)$ & 7 \\
Human Resources Management \& Empowerment & $8(15.7)$ & 2 \\
Client Orientation \& Customer Focus & $9(17.6)$ & 5 \\
Communication \& Information & $15(29.4)$ & 4 \\
Honesty \& Integrity & $18(35.3)$ & 4 \\
\hline
\end{tabular}

A relationship between respondent's biographics and current actual competency was tested by using one-way ANOVA tests-Kruskal-Wallis and Mann-Whitney $U$ test. Findings suggested no significant association between biographics and current actual competency level with $p$ value is $p>.05$ at $95 \%$ CI (see Table 6). 
Table 6. Associations between respondents' biographics and current actual competency level

\begin{tabular}{lllll}
\hline Biographics & Chi-square & df & Z & Sig. \\
\hline Age & 1.507 & 3 & - & 0.681 \\
Gender & - & - & -0.207 & $0.836^{*}$ \\
Types of Hospital & 0.246 & 2 & - & 0.884 \\
No. of Beds Available & 2.272 & 2 & - & 0.321 \\
Designation & 3.822 & 3 & - & 0.281 \\
Management Level & 3.380 & 2 & - & 0.185 \\
Academic Degree Obtained & - & - & -0.859 & $0.390^{*}$ \\
Degree Concentration & 0.136 & 2 & - & 0.934 \\
Duration of Work Experience & 1.424 & 2 & - & 0.491 \\
Trained in Hospital Management & - & - & -0.115 & $0.909^{*}$ \\
Total No. of Staffs & 3.513 & 3 & - & 0.319 \\
No. of Staff Directly Managed by Hospital Manager & 3.388 & 2 & - & 0.184 \\
\hline
\end{tabular}

Note. * Mann-Whitney $U$ tests

\section{Discussions}

Decisions made by an individual manager affect the organization's overall performance ${ }^{[9]}$. Poor management is unanimously blamed for the diminishing fortunes of most health industries ${ }^{[10]}$. The role of health managers is not as valued as the roles of surgeon, specialists, or clinical nurse. Experienced and evidence outside health care demonstrate that preparing people to lead teams to achieve results can produce: more productive staff; more satisfied patient; and stronger accountability and clearer results ${ }^{[11]}$.

The demographics of the respondents suggest that the women were less involved in the managerial positions of hospital management as this finding is similar to the study of the Pillay ${ }^{[12]}$. The majority of the respondents were from the non-administrative academic discipline and have had no any formal training attained in hospital management responsible for managing hospital in the Kathmandu Valley. Most hospitals are managed by doctors, most of these doctors combine clinical and managerial roles, most managers have received little or no formal training in management, if management training is available, and it has been academic or didactic in nature, there is a poor system for supporting managers to do their job. Most of the managers were currently working as middle level manager responsible for tactical jobs ${ }^{[13]}$ according to management hierarchy and level of management. This findings concern for access in hospital policy development and strategic execution in most of the hospitals.

The most developed competencies of honesty and integrity, service delivery innovation and communication and information with relatively least developed competencies of program and project management and knowledge management suggest that the management competencies will be learned more effectively if the training take place where people work, with the team that works together and when it addresses what they are experiencing as they do it their jobs ${ }^{[14]}$. The reason for the developed and least developed competencies among respondents depends upon the employing and practicing these competencies recurrently in daily jobs of hospital management.

Findings affirm the supposition of managerial competency lacking and developmental needs with significant difference exists in all generic competencies except communication and information and, honesty and integrity between current actual and ideal required level of competency rating. Which suggests that the respondents are "reasonably competent but not good" in all the generic competencies and provides the great need for further development ${ }^{[15]}$. No difference in honesty and integrity shows the hospital manager competently exchange information and ideas in a clear and concise manner appropriate for the audience in order to explain, persuade, convince and influence others to achieve the desired outcome. Respondents competently display and build the highest standards of ethical and moral conduct in order to 
promote confidence and trust in customers' services as the findings suggest no difference in honesty and integrity competency component.

The results of the survey demonstrate that the hospital manager valued strategic capability and leadership as a priority competency component. They feel that as a hospital manager they should be competent to provide a vision, set the direction for the organization and inspire others in order to deliver on the organizational mandate. Similarly, human resources management and empowerment regarded as a second one that suggests the importance of managing and encourage people, optimizing output and effectively manage the relationships among staffs are integral to hospital management. The least prioritized competencies of change management, financial management and program and project management suggests the limited scope of their work responsibility in hospitals as they are not practicing these competencies regularly to initiate and support organizational transformation, successful implementation of new initiatives, managing budgets, risk management, manage and monitor project activities in order to deliver desired outputs. Findings suggested no significant association between biographical variables and current actual competency level of respondents. Individual variables of respondents also did not significantly impact in current actual competency level of respondents.

\section{Conclusion}

The findings of this study back up the belief of managerial capacity lacking in the hospitals of Kathmandu Valley and there is a great need for the further development of managers in regards to competency development. These findings reflect the reality of the local hospital management environment and the developmental need of hospital manager. Managers who are currently working in the hospitals of Kathmandu Valley need to improve their managerial competencies by attending formal hospital management courses and trainings. Findings from this study will be useful to enhance current as well as future managerial competencies by employing new and innovative measures of management development programs with the combination of formal academic programs, formal instruction, in-house skill transfer training, and close mentoring and coaching which can link the competency gap among hospital managers of Nepal.

\subsection{Recommendations}

Based on the findings and developmental needs of respondents, the following recommendations emerged; formal education; management development programs; considering management as an integral to hospital service delivery systems; continuous competency assessment; and further studies associated with the competency of hospital managers.

At the academic level it is recommended that the need based short-term formal hospital/health management education program can be organized to scale-up competency level of working hospital managers. Curriculum and the courses of hospital/health care management can be revised in an academic setting. The initiative of Management Development Program (MDP) can be designed with new and creative approaches with the combination of formal instruction, in-house training, mentoring and coaching to bridge the competency gap. And management competencies will be learned more effectively if the training takes place where people work, with the team that works together and when it addresses what they are experiencing as they do their jobs. The workshop should be held in order to educate managers in recent management advances of theories and practices to improve their knowledge and skill needed for management function in hospitals.

In developing countries like Nepal, hospital management is an often overlooked. The first thing that comes to mind when you think of a hospital is a surgeon, paramedics and nurses. It is an essential to deem hospital management as an integral to hospital/healthcare service delivery systems. Investment in hospital manager, who work behind the scenes, controlling and directing hospital performances is solely leads to the sustainability of the hospital. And the formal recruitment system of hospital managers in government and public sector hospitals motivates them to thrive professionally as a competent hospital manager. 
In the organization level, developing a formal competency evaluation framework for a new hospital manager is essential. Periodic competency evaluations motivate hospital managers in continuing management education and learning which impact on improving the competency level of hospital manager. Various hospital management associations and alliances can be formed to formalize the competency assessment among hospital manager to get certified as a competent manager and to make this certification as a mandatory to work in hospitals and healthcare organizations.

Further research is needed to explore more in depth, especially in relation to the impact of hospital manager competency and hospital outcome. Further research linking competencies of hospital manager with outcome of care, growth and development of hospital is needed to study. The analysis in this study does not focus on the comparison of a skill gap between the public and private sector hospital manager, comparison of competency level is also an area for further investigation to assess the competency level. It will be exciting to investigate the impact of job satisfaction in the level of competencies among hospital managers. It is essential to take into account that the impact of ethnic and cultural backgrounds of managers with perception on competencies which can be affected by individual's backgrounds (race, religion, ethnic or cultural groups) is another area of study. Study of associations between competencies with individual and organizational variables is another area of research as this study does not indicate any significant association because of small samples. Future studies should use random or quota sampling and combine qualitative interviews with managers with quantitative approaches to explore more on managerial competencies of hospital manager.

The essential core competencies must be assessed for hospital managers leads to the control of and accountability for resources, effective management of personnel and assuring results. Dedicated team of professionals in the form of distinctly qualified managers and their competency at work are vital to success of any hospitals.

\subsection{Limitations}

The managerial competencies are difficult to measure by its nature a complex process. It is important to note that the findings of this study have limited within Kathmandu Valley and might need further exploration. It is assumed that most of the tertiary and specialty hospitals are operating within Kathmandu Valley with a limited hospital management practice. The findings presented in this study based upon purely subjective rating and self assessment of respondents might be influenced by the respondents' lack of knowledge and confidence with the statements. With this limitation in mind, this study assessed the managerial competencies of hospital manager and the findings highlighted the overall level of competency with gaps in the competency profile and important competency component as regarded by the respondents.

\section{Conflict of interest}

The authors declare no conflict of interest. Name of the institution to which the research work attributed; Department of Health Care Management, National Open College, Faculty of Management Studies, Pokhara University, Nepal. The study was conducted under the Master of Health Care Management degree research requirements under Pokhara University, Nepal. All rights of the SMS Competency Framework reserved to RSA Department of Public Service and Administration: The SMS Handbook (2003).

\section{Acknowledgements}

We would like to acknowledge Prof. Dr. Jaya Krishna Pathak, Principal of National Open College (NOC), Pokhara University, Nepal for his generous support, Mr. Purushottam Dhakal, Bio-statistician of Nepal Health Research Council (NHRC), Ramshahpath, Kathmandu for his support on statistical analysis and Mr. Miroj Shrestha for his support in data enumeration and field work. We would also extend our gratitude to all hospital managers of Kathmandu Valley for their willingness to participate and support in providing necessary information to accomplish this research.

\section{References}

[1] Lehman U, Blom W, Dlanjwa M, Fikeni L. Investigating the Roles and Functions of Clinic Supervisors in the Eastern Cape Province. HST Technical Report. Health Systems Trust, Durban, 2002. 
[2] Mishra RC. Management for Doctors, J Nepal Med Assoc. 2008; 47(171): 172-3. PMid: 19079387.

[3] Hellriegel D, Jackson ES, Slocum J, Staude G, Amos T, Klopper HB, et al. Management 2nd Edition. Oxford University Press: South Africa; 2004.

[4] Egger D, Travis P, Dovlo D, Hawken L. Strengthening Management in Low-income Countries. Making Health Systems Work Series - Working Paper 1. Geneva, World Health Organization, 2005.

[5] Egger D, Ollier E, Tumusiime P, Bataringaya J. Strengthening Management in Low-income Countries: lessons from Uganda. Making Health Systems Work Series - Working Paper 11. Geneva, World Health Organization, 2007.

[6] Dorgan S, Layton D, Bloom N, Homkes R, Sasun R, Reenen JV. Management in Healthcare: Why good practice really matters, McKinsey and Company, London School of Economics, Harvard University, 2010.

[7] Wikipedia. List of hospitals in Nepal [Online]. [Cited 2 June 2012]. Available from: http://en.wikipedia.org/wiki/List_of_hospitals_in_Nepal.

[8] SMS Competency Framework, RSA Department of Public Service and Administration: SMS Handbook - Chapter 5: Competency Framework, 2003 [Online]. [Cited 2 June 2012]. Available from: http://sa-health.wikidot.com/sms-competency-framework.

[9] Buchbinder SB, Shanks NH. Introduction to Healthcare Management. 2nd Edition, Chapter-II: Understanding Healthcare Management, Jones \& Bartlett Publishers, 2012.

[10] Oleribe OOE. Management of Nigerian health care institutions: A cross sectional survey of selected health institutions in Abuja Nigeria, Journal of public administration and policy research. 2009 August; Vol. 1(4) pp: 063-067.

[11] Dwyer J, Paskavitz M, Vriesendorp S, Johnson S. An urgent call to professionalize leadership and management in healthcare worldwide. Occasional Papers. No. 4, Management Science for Health. 2006.

[12] Pillay R. The skills gap in hospital management: a comparative analysis of hospital managers in the public and private sectors in South Africa. doi:10.1258/hsmr.2009.009015 Health Serv Manage Res. 2010 February; vol. 23(1) pp: 30-36. http://dx.doi.org/10.1258/hsmr.2009.009015

[13] Lussier RN. Management Fundamentals: Concepts, Applications, Skills Development. 3rd Ed. Thomson South-Western: United States of America; 2006.

[14] Filerman GL. Closing the management competence gap. Human Resources for Health. 2003; 1: 7. http://dx.doi.org/10.1186/1478-4491-1-7

[15] Pillay R. Managerial competencies of hospital manager in South Africa: a survey of managers in the public and private sectors. Human Resources for Health. 2008; 6: 4. http://dx.doi.org/10.1186/1478-4491-6-4 